\title{
'n Beskouing oor die finansiering van navorsing aan universiteite
}

\section{FUNDAMENTELE OORWEGINGS}

By die oorweging van die finansiering van navorsing aan universiteite is dit nodig om te besluit binne watter raamwerk die saak benader moet word.

\subsection{Nasionale navorsingsbesteding}

1.1.1 Die eerste en waarskynlik belangrikste raamwerk vir hierdie doel is dié van navorsingsbesteding op nasionale vlak. Hier kan gedink word aan die persentasie van die Bruto Nasionale Produk wat in Suid-Afrika aan navorsing en ontwikkeling bestee word. Daar is rede om te glo dat hierdie persentasie veels te klein is.

1.1.2 Ons kan ook die rol van die universiteite in die nasionale navorsingspoging bekyk en, met inagneming van hierdie rol, besluit of die besteding aan navorsing aan universiteite ' $n$ regmatige deel van die totale navorsingsbesteding uitmaak. Dat die universiteite 'n unieke rol te speel het, is duidelik, gesien die belangrikheid van die universitêre opleiding van die toekomstige navorsingsmannekrag vir die ontwikkeling en stimulering van navorsing in ons land. Die nog onvoltooide ondersoek na die navorsingspotensiaal op die gebied van die Natuurwetenskappe en die Ingenieurswese by ons universiteite het reeds getoon dat die huidige voorsiening vir die ondersteuning van navorsing aan universiteite nie naby genoeg is om die bestaande potensiaal ten volle te benut nie.

\subsection{Besteding aan universiteitsnavorsing}

Ten tweede is daar die kleiner raamwerk van die totale besteding aan navorsing by universiteite alleen. Hier gaan dit om die hantering van die staatsfondse wat vir navorsing aan die universiteite beskikbaar gestel word. Die doel is natuurlik 'n stelsel wat tot optimale navorsing en die optimale opleiding van navorsers sal lei. Wat hier volg, is 'n bespreking van die probleem van die hantering van fondse en nie van die vraagstukke binne die raamwerk van nasionale navorsingsbesteding nie.

1.2.1 Verreweg die grootste bydrae tot universiteitsnavorsing moet uit die aard van die saak uit die algemene toekenning (met ander woorde: die subsidie) kom. Navorsing en die opleiding van navorsingstudente is ' $n$ deel van elke universiteitsdosent se pligte en derhalwe kan 'n deel van die salaris van elke dosent as navorsingsbesteding beskou word. Net so is 'n deel van die koste verbonde aan die voorsiening van geboue, apparatuur, dienste en dies meer ook navorsingskoste. Met ander woorde: die ver- skaffing van die infrastruktuur vir navorsing moet uit die aard van die saak deur die subsidie gedek word.

1.2.2 Wat die bykomende koste van navorsing bo en behalwe die verskaffing van die infrastruktuur betref, is dit duidelik dat ' $n$ toekenning volgens 'n formule gebaseer op statistiese faktore (byvoorbeeld die studentetal) nie langer bevredigend is nie. So 'n toekenning moet eerder bepaal word op grond van die aard van die navorsing en die koste wat aan die navorsing verbonde is. Navorsing in sommige rigtings is geweldig duur; ander navorsing is betreklik goedkoop. Dit is byvoorbeeld duur wanneer duur apparatuur vereis word om op internasionale vlak met ander navorsers te kan meeding, of wanneer die voortdurende gebruik van duur chemikalieë onvermydelik is, of in die geval van teoretiese navorsing wat van die beskikbaarheid van groot en gesofistikeerde rekenaars afhanklik is, ens. Aan die ander kant is daar navorsers van gehalte wat betreklik min nodig het om hul werk doeltreffend te kan doen. Vanweë die waarskynlik ongelyke verdeling van navorsers onder die universiteite en ook die verdeling van navorsers in duur en goedkoop navorsers, en verder vanweë die feit dat hierdie verdeling van tyd tot tyd kan verander sonder verandering in die statistiese faktore waarvan die subsidie tans afhang, moet die finansiering van navorsing klaarblyklik nie op 'n statistiese basis nie, maar op 'n selektiewe basis geskied.

1.2.3 Selektiewe toekennings, in die sin waarin dit hier gebruik word, beteken toekennings aan individue waarvan elkeen se vermoëns en behoeftes afsonderlik deur oordeelkundige evalueerders bepaal word. Met ander woorde: toekennings word op grond van deskundige oordeel oor individue bepaal en nie volgens formules nie. Ek wil hier beklemtoon dat ek die voorgestelde navorsingskomponent in die nuwe subsidieformule, wat berus op die administratiewe bepaling van die aantal publikasies volgens sekere reëls, nie as selektief beskou nie.

1.2.4 Om op te som: In beginsel moet die voorsiening van fondse vir navorsing aan universiteite twee komponente behels, naamlik (a) 'n toekenning vir die verskaffing van die infrastruktuur, wat noodwendig deel moet uitmaak van die algemene subsidie wat deur statistiese faktore soos die studentetal bepaal word, en 
(b) 'n selektiewe toekenning gebaseer op die individuele navorsers aan die universiteite, hulle bevoegdhede en hulle regmatige vereistes volgens die soort navorsing wat hulle doen. Beslissings oor die selektiewe toekennings moet uit die aard van die saak die verantwoordelikheid wees van 'n agentskap of agentskappe buite die universiteite. Die verantwoordelike agentskap moet beskik oor die nodige organisasie vir die betroubare evaluering van die betrokke navorsers se meriete en behoeftes om te verseker dat daar tussen goeie en minder goeie aansoekers gedifferensieer word.

1.2.5 Hoewel dit in beginsel moontlik is om die verantwoordelikheid vir alle navorsingstoekennings tot op die laagste vlak aan so 'n agentskap oor te laat, sou dit administratief baie lomp en omslagtig wees. Waarskynlik sal 'n betreklik groot persentasie universiteitsdosente volgens ' $n$ streng gedifferensieerde toekenningskema slegs klein toekennings ontvang en sal daar nie veel onderskeid tussen hulle gemaak hoef te word nie. Dit sou dus maklik wees as die verantwoordelikhede van die universiteite en die buiteagentskap so verdeel word dat die agentskap slegs vir die finansiering van die navorsing van 'beproefde' navorsers verantwoordelik gehou word, en die universiteite uit subsidiefondse vir die ander voorsiening maak. 'n Beproefde navorser is ' $n$ navorser wat reeds goed op dreef is, wat gereeld publiseer en wat deur sy publikasies reeds by sy medenavorsers bekend is. Vir die behoeftes van navorsers op 'n laer vlak kan voorsiening gemaak word uit 'n subsidiekomponent wat, soos in die geval van die Van Wyk de Vries-subsidieskema, 'n klein persentasie van die totale salaristoekenning vir akademiese personeel kan uitmaak. Dit is so omdat dié groep taamlik homogeen sal wees wat hulle navorsingsbehoeftes betref, en omdat die grootte van die groep taamlik direk in verhouding sal wees tot die grootte van die totale akademiese personeel, wat weer regstreeks verband hou met die vernaamste statistiese faktor van die subsidie, naamlik die studentetal.

\section{GRONDBEGINSELS VIR 'N SELEKTIEWE TOEKENNINGSTELSEL}

\subsection{Ondersteuning op grond van prestasie}

Daar moet besef word dat as ' $n$ mens die beskikbare fondse doeltreffend wil gebruik, dit bestee moet word aan die ondersteuning van kandidate wat na alle waarskynlikheid goeie navorsing sal doen. Die waarskynlike toekomstige prestasies van navorsers kan alleen geskat word deur te kyk na hulle prestasies in die verlede, en veral in die betreklik onmiddellike verlede. Hieruit kan die volgende beginsel afgelei word: Ondersteuning moet in die eerste plek gebaseer word op ' $n$ evaluering van die kandidaat as navorser op grond van sy reeds behaalde prestasies, veral in die onmiddellike verlede, soos gemeet aan sy publikasies en ander openbare bydraes tot sy vak en die mate waarin hy deur die internasionale gemeenskap van navorsers aanvaar word, ò as 'n leier of hoog aangeskrewe lid van die gemeenskap ò as 'n beproefde navorser.

\subsection{Navorsingsvryheid}

As ' $n$ mens hierdie beginsel aanvaar, bly daar nog die kwessie van die waarde wat by die oorweging van toekennings geheg behoort te word aan die projek of die navorsingsgebied wat die navorser in die oog het. Dit lê voor die hand dat die ideale toestand sou wees dat 'n goeie navorser die vryheid gegun word om te besluit watter navorsing hy wil doen. Beperkings op sy vryheid van keuse sal beslis nie sy prestasies verbeter nie en gevolglik moet ons aanvaar dat dit of geen uitwerking sou hê nie òf dat dit sy werk nadelig sou beïnvloed. Daar kan omstandighede wees waarin navorsing op besondere gebiede wenslik sou wees, maar by universiteite is vryheid van navorsingskeuse die reël, en dit behoort dan ook die geval te wees by selektiewe ondersteuning deur middel van 'n buiteagentskap, sekerlik op die eerste vlak van ondersteuning. Dit is natuurlik moontlik dat ondersteuning op ander vlakke in die nasionale belang of om ' $n$ ander rede wel vir navorsing in bepaalde rigtings beskikbaar gestel kan word. Maar, om te herhaal, die basiese ondersteuning van goeie navorsers aan die universiteite moet die ondersteuning van vrye navorsing wees. Hieruit vloei dus die volgende grondbeginsel: Ondersteunde navorsers moet algehele vryheid geniet ten opsigte van die projekte wat hulle wil aanpak, en die rigting waarin hulle wil werk.

\subsection{Gehalte en behoeftes van navorser}

'n Derde belangrike punt is die vlak van ondersteuning op grond van (a) die $k$ waliteit van die navorser soos deur evaluering bepaal, en (b) sy behoeftes na gelang van die rigting waarin hy werk, die projekte wat hy aanpak, ens. Daar moet aanvaar word dat die beskikbare fondse vir die ondersteuning van navorsing nooit genoeg gaan wees om aan almal se vereistes te voldoen nie. Verder is daar by alle ondersteuning ' $n$ mate van risiko teenwoordig. Daar sal gevalle wees waar die verwagtings waarop die ondersteuning gebaseer is, nie verwesenlik word nie, maar hoe hoër die geëvalueerde kwaliteit van die kandidaatnavorser, hoe kleiner word die risiko. Dit het dus sin om streng te differensieer met betrekking tot die verhouding tussen die bedrag wat toegestaan word, en die redelike behoeftes van die navorser. Met ander woorde: dit sou sinvol wees om die uitmuntende navorser feitlik alles te gee wat hy redelikerwys kan gebruik, terwyl 'n heelwat laer verhoudingsyfer vir navorsing op 'n laer vlak gebruik kan word. Dit lei tot die derde beginsel: Ten opsigte van die vlak van ondersteuning op grond van die redelike behoeftes van die navorser, moet streng tussen navorsers van besondere gehalte en dié van laer gehalte gedifferensieer word. 


\subsection{Maatstaf op grond van evaluering}

As hierdie drie beginsels aanvaar word, sal die administrasie van toekennings waarskynlik drasties vereenvoudig kan word. Die deurslaggewende evaluering van die kandidaat as navorser sal natuurlik die oorweging van gedetailleerde aansoeke om finansiering moet voorafgaan, maar evaluering kan ook geheel en al onafhanklik van sulke aansoeke lank voor die sluitingsdatum vir aansoeke uitgevoer word. As die evaluering eenmaal afgehandel en huidige navorsers daarvolgens op ' $n$ ranglys geplaas is, sal daar 'n maatstaf wees waarvolgens aansoeke om finansiering te eniger tyd beoordeel kan word. Daar moet natuurlik mettertyd die geleentheid gebied word om aanvullende inligting voor te lê en sistematiese heroorweging moet deel van die stelsel uitmaak. As die stelsel op dreef is, sal dit egter aansienlike tydsbesparing meebring omdat die herhaalde ad hoc-beoordelings, wat deel van die meeste bestaande stelsels is, uitgeskakel sal word. Buitendien, omdat die evaluering binne die raamwerk van 'n algemene evaluering van die navorsers sal geskied, sal dit noodwendig betroubaarder wees as 'n reeks ad hoc-beoordelings wat sonder verdere verwysing uitgevoer word elke keer wanneer 'n aansoek voorgelê word.

\section{DIE NAVORSINGSKOMPONENT IN DIE NUWE SUBSIDIEFORMULE VIR UNIVERSITEITE}

\subsection{Publikasies as maatstaf}

Die nuwe subsidieformule, soos uiteengesit in die verslag oor die ondersoek na staatsfinansiering van universiteite (SANSO 110), maak voorsiening vir 'n navorsingskomponent gebaseer op die aantal publikasies wat aan sekere vereistes voldoen, en wat in die voorafgaande jare verskyn en uit navorsing binne die betrokke universiteit voortgespruit het. So 'n toekenning word beskou as ' $n$ direkte beloning aan die universiteit vir die navorsing wat daar gedoen is. Die beginsel is hoogs aanvaarbaar, maar dit bly ' $n$ statistiese metode wat administratief toegepas word, en wat nie naby sensitief genoeg is om regverdige erkenning vir goeie navorsing te gee nie. Die blote tel van publikasies, al is dit byvoorbeeld net dié wat in die Citation Index verskyn het, is 'n veels te growwe maatstaf. Hoe neem mens binne die perke van 'n redelik eenvoudige telsisteem die verskil in aanmerking tussen monografieë wat die werk van jare verteenwoordig, en kort publikasies, as hulle elkeen as een eenheid getel word? Die belangrikheid van 'n publikasie is ook nie meetbaar volgens die aantal bladsye of volgens die aantal vermeldings in die Citation Index nie. Evaluering deur deskundiges wat in staat is om al die fasette van navorsingsproduksie en navorsingskwaliteit in ag te neem, is die enigste manier om navorsing regverdig te beoordeel. Die nuwe formule bied ook ruim geleentheid vir die uitbuiting van die stelsel. Die wete dat duisende rande per publikasie op die spel is, kan en sal sonder twyfel aktiwiteite aanmoedig wat wel die subsidie sal verhoog, maar wat tog nie ware navorsing sal bevorder nie. Dit sou raadsaam wees om hierdie formule in heroorweging te neem. Myns insiens behoort 'n statisties bepaalde navorsingstoekenning weer ingestel te word en behoort die selektiewe ondersteuning van navorsers oorgelaat te word aan 'n buiteagentskap wat hom daarop toespits om ondersteuning te verleen wat op navorsing van hoë kwaliteit gegrond is.

\subsection{Doseerverpligtings}

Volgens baie universiteitsnavorsers van aansien is een van die groot struikelblokke in die weg van meer en beter navorsing aan ons universiteite die feit dat hulle te veel doseer- en ander universiteitsverpligtings het. Een van die redes waarom dit so is, is dat by die meeste universiteite in ons land, doseer- en ander pligte gelykop onder die personeel van departemente verdeel word, ten spyte daarvan dat party dosente baie min of geen navorsing doen nie, terwyl ander baie aktiewe en produktiewe navorsers is. Daar word van alle dosente verwag om te doseer en om navorsing te doen, maar dit beteken nie dat bogemiddeld aktiewe navorsers nie minder as die gemiddelde doseerverpligtings kan hê nie en dat, as die navorsing in 'n departement bo gemiddeld is, die departement nie addisionele fondse behoort te kan bekom om navorsers se doseerverpligtings te verminder nie. Dit is in hierdie verband dat die voorgestelde publikasiekomponent in die nuwe subsidiebedeling tog 'n belangrike rol kan speel, nie as 'n navorsingstoekenning nie, maar as ' $n$ hulpmiddel om in departemente of waar bogemiddelde navorsing ook al plaasvind, verligting van doseerpligte moontlik te maak. Dit sou meebring dat hierdie besondere komponente nie, soos die res van die subsidie, vry van enige beperking moet wees nie, maar dat die toepassing daarvan juis beperk moet word tot die verligting van doseerlaste in instansies binne die universiteit waar hoogstaande navorsing gedoen word.

\subsection{Berekening van toekenning op grond van publikasies}

Dit kom my voor of die publikasiekomponent in die voorgestelde en in beginsel aanvaarde nuwe sub sidiestelsel, soos dit in SANSO 110 uiteengesit word, juis op hierdie probleem gerig is - hoewel dit nooit uitdruklik gesê word nie. Volgens die nuwe subsidieformule word die ou komponent vir die voorsiening vir personeel in universiteitsdepartemente (gebaseer op die Van Wyk de Vries-aanbevelings) in twee komponente verdeel, naamlik 'n komponent vir formele onderrig en 'n komponent vir navorsing. Die navorsingskomponent beloop omtrent 'n derde van die totale toekenning vir die Natuurwetenskappe en omtrent 'n kwart vir die Geesteswetenskappe. Dan word 'n deel (omtrent 'n derde) van die navorsingskomponent weggeneem en beskou as die deel van die navorsingskomponent wat aan navorsingsproduksie gekoppel behoort te word. Let daarop dat hierdie navorsingskomponent dié deel van die salarisvoorsiening is wat as navorsingskoste gereken word. Die totale bedrag wat so van die toekenning aan alle universiteite weggeneem word, gedeel deur die totale 
getal kwalifiserende publikasies gedurende 1981, word dan uitgedruk as 'n persentasie (20 persent) van 'n kostekomponent wat van akademiese salarisvlakke afhang, en hierdie bedrag word die toekenning per publikasie wat in die formule ingebou is. Dit is ' $n$ indeksgekoppelde bedrag wat in 1981 baie na aan R5 000 was, en nou volgens die nuutste subsidieberekening omtrent $R 7080$ is. Wat belangrik is, is dat as gevolg van die manier waarop die bedrag op grond van kwalifiserende publikasies in 1981 bepaal is, die uitwerking in 1981 sou gewees het dat die totale publikasiekomponenttoekenning aan universiteite gelyk sou wees aan die totaal van die navorsingskomponente wat van al die universiteite weggeneem is. Maar die verspreiding van daardie totaal onder die universiteite sou ongelyk wees in dié sin dat die universiteite met 'n beter as gemiddelde prestasie wat publikasies betref, 'n groter as gemiddelde deel van die totale bedrag sou ontvang, terwyl die swakker presterende universiteite minder as die gemiddelde sou kry.

\subsection{Studente-personeelverhouding}

Dieselfde beginsel sal in later jare geld, met ander woorde 'n deel van die totale ou personeelvoorsiening sal herverdeel word onder die universiteite, maar op 'n ongelyke wyse, wat van die kwalifiserende publikasies sal afhang. Die belangrike punt is dat die publikasiekomponent deel van die personeelkomponent uitmaak. Hierdie voorsiening is klaarblyklik vir die finansiering van akademiese personeel bedoel, maar omdat die verdeling op grond van navorsingsproduktiwiteit geskied, behoort dit aangewend te word om beter as gemiddelde studente-personeelverhoudings te handhaaf in universiteitsdepartemente waar baie navorsing gedoen word.

\subsection{Aanbevelings}

Ek wil dus die volgende aan die hand doen:

3.5.1 Vir die voorsiening in die navorsingsbehoeftes van personeel wat nie hulp van 'n buiteagentskap ontvang nie, moet iets soos die ou komponent in die Van Wyk de Vries-formule weer in die subsidieformule ingesluit word.

3.5.2 Die huidige publikasiekomponent moet bly voortbestaan, maar die stelsel waarvolgens kwalifiserende publikasies ingesluit en getel word, moet in heroorweging geneem word. Hierdie toekenning moet dan tot die verligting van die doseerpligte van aktiewe navorsers beperk word ten einde die volle benutting van hulle potensiaal moontlik te maak.

\subsection{Slot}

Dit het tog nie sin om 'n goeie stelsel vir die ondersteuning van navorsing deur middel van 'n buiteagentskap in werking te stel nie as begaafde navorsers, weens gebrek aan fondse by ons universiteite en onvoldoende finansiering deur die owerheid, nie die geleentheid gebied word om optimaal te funksioneer nie.

J.S. de Wet 